\title{
Alkoholforbruk - en naturlig del av anamnesen
}

\author{
Spørsmål omkring bruk av nikotin og alkohol bør være en naturlig del av anamneseopptaket ved innleggelse \\ i somatisk avdeling.
}

I en kartlegging av risikofylt alkoholbruk vi har gjennomført i medisinske avdelinger ved Sørlandet sykehus, fant vi at 9,3\% av 536 pasienter hadde hatt et slikt forbruk i tiden før innleggelsen. Pasientene oppga at alkoholbruk ble kartlagt i mindre grad enn røyking (1).

Helsekadene av nikotinbruk er allment kjent, og det er satt inn flere tiltak for å forebygge røyking. Det ble forbudt å reklamere for tobakksvarer i Norge i 1973, og senere innførte Helsedirektoratet påbud om advarsel om helsefaren på alle tobakksprodukter. Forbud mot røyking på alle serveringssteder kom inn i røykeloven med virkning fra 1. juni 2004. Sakte, men sikkert er nikotinbruk blitt harryfisert og røykere stigmatisert. Stadig færre ungdommer begynner å røyke, og bare $13 \%$ av den voksne befolkning er nå dagligrøykere (2). Å spørre pasienter om nikotinbruk i anamneseopptaket oppleves som legitimt av helsepersonell (3).

Det er annerledes med alkoholbruken. Holdningene i samfunnet er todelt. Alkohol er en lovlig vare, riktignok til en viss grad regulert med reklameforbud og omsetning av sterkøl, vin og brennevin kun på Vinmonopolet. Helseskader kan oppstå, men dette gjelder vel bare stordrikkere? Dessuten kan alkohol gi glede. Fredagspilsen, vinlotteriet på arbeidsplassen, avisenes og tidsskriftenes ukentlige vinspalter dreier seg om dette. Politikerne har vedtatt økte taxfreekvoter.

En synkende andel bruker aldri alkohol i 2012 var den nede i $12 \%$ (4). Kvinner og eldre mennesker bruker alkohol mer enn før (5). Leger og helsepersonell drikker også alkohol. Vi har inntrykk av at alkoholbruk oppleves som en privatsak, som noe man ikke bør stille spørsmål ved. Samtidig vet vi at jo større forbruket er, desto flere skader oppstår (6). Bør vi la være å spørre om folks bruk av alkohol av frykt for å blande oss inn i deres privatliv?
Vi mener svaret er nei. Alkoholbruk er hovedårsak eller medvirkende årsak til minst 60 forskjellige sykdommer (7). Det er estimert at alkoholen tar mer enn 1200 liv per år (8). I tillegg kommer skader på familie og barn. Pasientene i vår studie oppga at alkoholbruk ble kartlagt i mindre grad enn tobakksbruk. På bakgrunn av dette mener vi bevisstheten om å inkludere spørsmål om bruk av alkohol i det vanlige anamneseopptaket bør styrkes (1). Hvordan kan dette gjøres?

\section{Hvordan kartlegge alkoholbruk?}

Allerede i 1961 anbefalte professor Rasmussen i sin veiledning for legestudenter: «Forholdet til alkohol må også belyses. Det er naturlig å ta dette sammen med tobakken, og det er naturlig å begynne med tobakken, idet spørsmålet om alkohol da ikke får en så støtende karakter. Man glir lett og naturlig fra spørsmålet om tobakk over til alkoholforbruket» (9).

Nasjonale faglige retningslinjer anbefaler bruk av CAGE-verktøyet i somatiske og psykiatriske avdelinger for å kartlegge alkoholbruk, fordi man mener dette er velegnet innenfor tjenester hvor rusbehandling ikke er hovedmålsettingen $(10,11)$. CAGE består av fire spørsmål:

- Har det noen gang hendt at du har startet dagen med å drikke alkohol for å roe nervene eller bli kvitt bakrusen?

- Er du blitt irritert over at andre har kritisert drikkevanene dine?

- Har du noen gang hatt skyldfølelse på grunn av alkoholbruken din?

- Har du noen gang tenkt at du burde drikke mindre?

Positive funn ( $\geq 2$ ja) betyr sannsynlig alkoholmisbruk eller alkoholavhengighet.

CAGE-testen inneholder imidlertid ikke spørsmål om det faktiske forbruket og er dermed ufullstendig. Dette er uheldig, siden

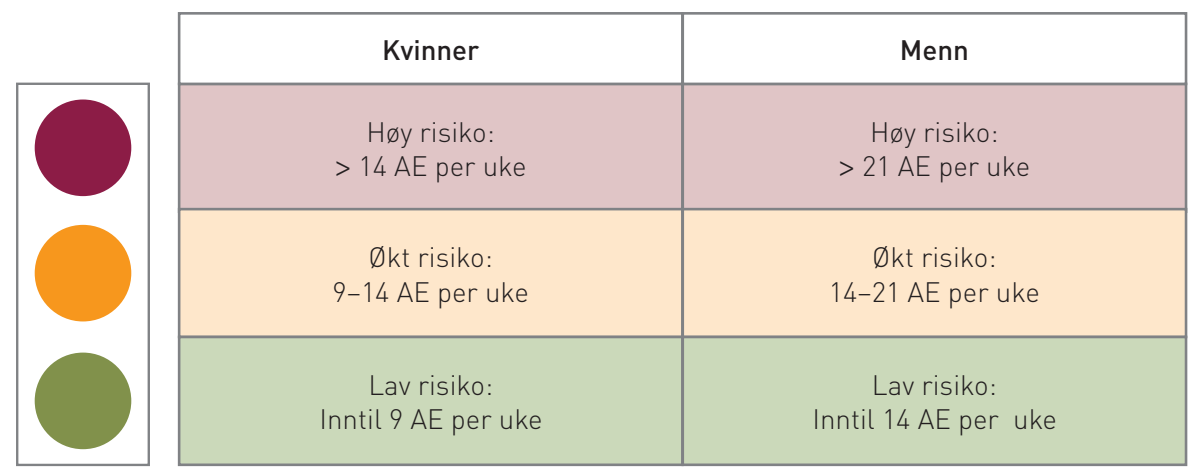

Figur 1 Anbefalte grenseverdier for ulike risikokategorier av alkoholbruk i trafikklystermer (15). Eldre > 67 år bør følge grenseverdier for kvinner (16)

\section{RAMME 1}

En alkoholenhet (AE) inneholder $13 \mathrm{~g}$ ren alkohol, som tilsvarer omtrent:

- En rusbrus eller sider

- En flaske øl (pils) på $33 \mathrm{cl}$

- Ett glass vin på $12 \mathrm{cl}$

- Ett glass hetvin på $8 \mathrm{cl}$

- En drink (konjakk, whisky, vodka) på $4 \mathrm{cl}$

man da kommer bort fra en instrumentell kartlegging og spørsmål om skyld og irritasjon lett kan oppfattes om verdiladede. I stedet kan man bruke AUDIT-testen med ti spørsmål, som kartlegger forbruk, drikkemønster, avhengighet til alkohol og konsekvenser. Validerte kortversjoner med tre (Audit-C) eller fire (Audit-4) spørsmål kan også anbefales $(12,13)$.

En enda enklere fremgangsmåte i en stresset hverdag vil være å spørre på samme måte som for tobakk, kun med vekt på konkret forbruk. I stedet for et ja-nei-spørsmål om hvorvidt pasienten bruker alkohol, kan det intuitive «Når drakk du alkohol sist?» passe. Selvfølgeligheten i spørsmålet gjør at vedkommende ikke uten videre vil benekte bruk (14).

Vår studie viste at det i en populasjon med høy alder var opptil $40 \%$ som anga at de ikke hadde brukt alkohol siste år, og dette ene spørsmålet er da tilstrekkelig (1). For dem som har drukket alkohol siste år, går man videre og spør om forbruket siste uke. Man kan kartlegge bruken i standard salgsstørrelse og selv regne dette om i antall alkoholenheter (AE) per uke (ramme 1). Forbruket noteres ned, og ut i fra hvor mange alkoholenheter som konsumeres ukentlig, kan det avgjøres om pasienten befinner seg i grønn, gul eller rød sone (fig 1) $(15,16)$. Forutsetningen er at den som stiller spørsmålene, raskt kan omgjøre vanlige salgsstørrelser til alkoholenheter.

Oppfølging i etterkant av kartlegging Hva med oppfølging i etterkant for dem med risikofylt forbruk? Spesifikk kartlegging av alkoholbruken er en forutsetning for å kunne uttale seg om det. Når man har fătt implementert en slik strukturell kartlegging, åpner det for at man kan gi pasienten direkte tilbakemelding på vedkommendes forbruk med trafikklysbegreper og anbefale forbruk i «grønn sone», alternativt at pasienten har en sykdom/tilstand der man vil anbefale totalavhold (fig 1).

Pasienten får beskjed dersom han havner 
i gul eller rød risikosone, og dette noteres $i$ epikrisen til fastlegen. Alternativt kan pasienter i rød sone motiveres og henvises til tverrfaglig spesialisert rusbehandling (TSB). Det bør også gis informasjon om hvilke selvhjelpstiltak som kan være aktuelle.

\section{Øistein Kristensen}

oistein.kristensen@sshf.no

John-Kåre Vederhus

Øistein Kristensen (f. 1945) er spesialist i psykiatri, overlege og seniorforsker ved Avdeling for rus og avhengighetsbehandling, Sørlandet sykehus, Kristiansand.

Forfatter har fylt ut ICMJE-skjemaet og oppgir ingen interessekonflikter.

John-Kåre Vederhus (f. 1960) er ph.d. og forsker ved Avdeling for rus og avhengighetsbehandling, Sørlandet sykehus, Kristiansand. Forfatter har fylt ut ICMJE-skjemaet og oppgir ingen interessekonflikter.

\section{Litteratur}

1. Vederhus JK, Rysstad O, Gallefoss F et al. Kartlegging av alkoholbruk og røyking hos pasienter innlagt i medisinsk avdeling. Tidsskr Nor Legeforen 2015; 135: $1251-5$

2. Skretting A, Lund KE, Bye EK. Rusmidler i Norge 2014. Oslo: SIRUS, 2014

3. Demmert A, Grothues JM, Rumpf HJ. Attitudes towards brief interventions to reduce smoking and problem drinking behaviour in gynaecological practice. Public Health 2011; 125: 182-6.

4. Bye EK, Amundsen EJ, Lund M. Bruk av tobakk, rusmidler og vanedannende legemidler i Norge hovedfunn fra SIRUS' befolkningsundersøkelse i 2012. SIRUS-rapport 6/2013. Oslo: SIRUS, 2013.

5. Krokstad S, Knudtsen MS. Folkehelse i endring helseundersøkelsen i Nord-Trøndelag (HUNT). Levanger: HUNT, 2011

6. Storvoll EE, Rossow I, Moan IS et al. Skader og problemer forbundet med bruk av alkohol, narkotika og tobakk. Oslo: SIRUS, 2010.

7. Rehm J, Room R, Graham K et al. The relationship of average volume of alcohol consumption and patterns of drinking to burden of disease: an over view. Addiction 2003; 98: 1209-28.

8. Fekjær HO. Rus: bruk, motiver, skader, behand ling, forebygging, historie. 3. utg. Oslo: Gyldendal Akademisk, 2009.

9. Rasmussen H. Pasientundersøkelser og journalskriving: veiledning og retningslinjer for studenter Bergen: John Grieg. 1961

10. O'Brien CP. The CAGE questionnaire for detection of alcoholism: a remarkably useful but simple tool. JAMA 2008; 300: 2054-6.

11. Helsedirektoratet. Nasjonal faglig retningslinje for utredning, behandling og oppfølging av personer med samtidig rus - og psykisk lidelse - ROP-lidelser. Oslo: Helsedirektoratet, 2012

12. Babor T. Higgins-Biddle JC. Saunders JB et al. AUDIT - The Alcohol Use Disorders Identification Test. Genève: WHO, 2001

13. Gual A, Segura L, Contel M et al. Audit-3 and audit-4: effectiveness of two short forms of the alcohol use disorders identification test. Alcohol Alcohol 2002; 37: 591-6.

14. Lien L. Rusmiddelbrukspyramiden. Nasjonal kompetansetjeneste for samtidig rusmisbruk og psykisk lidelse. www.snakkomrus.no/safari/ safari snakkomrus 2.html (16.3.2015).

15. Skjøtskift S. Alkohol som medvirkende faktor i noen vanlige kliniske situasjoner. Tidsskr Nor Lægeforen 2003; 123: 185-7.

16. Crome I, Dar K Janikiewicz S et al. Our invisible addict: First Report of the Older Persons' Substance Misuse Working Group of the Royal College of Psychiatrists. London: Royal College of Psychiatrists, 2011

Mottatt 20.3. 2015, første revisjon innsendt 12.5. 2015, godkjent 27.5. 2015. Redaktør: Hanne Støre valeur. 